\title{
Effects of Heat Treatment Systems on the Physical Properties of Coated Scots pine (Pinus sylvestris L.) and poplar (Populus euramericana)
}

\begin{abstract}
Ahmet Can *
Heat treatment is an environmentally friendly and efficient way to improve the properties of wood species. These treatments alter the substrates and can influence the surface properties of the varnish coatings. This paper investigated the effects of heat treatment on the physical properties of open and close systems Scots pine (Pinus sylvestris L.) and poplar (Populus euramericana) wood, coated with water-based, polyurethanebased, and oil/wax-based varnishes. Heat treatment was applied at the temperatures of $190,212{ }^{\circ} \mathrm{C}$ for pine and $180,200{ }^{\circ} \mathrm{C}$ for poplar, respectively. Color, gloss, and roughness tests were carried out for each of the coatings. Higher mass loss occurred in pine samples with heat treatment as compared to vacuum-heat treatment. Gloss decreased in OIL+WAX treatment and color change increased after the heat treatment, but these results were inhibited with vacuum-heat treatment. Maximum roughness was obtained in PUR varnishes and minimum roughness in OIL + WAX samples. The low roughness values provide some advantages in application.
\end{abstract}

Keywords: AQUA varnish; PUR varnish; OIL+WAX varnish; Close system heat treatment; Surface properties

Contact information: Department of Forest Industrial Engineering, Faculty of Forestry, Bartin University, Bartin 74100 Turkey; *Corresponding author: acan@bartin.edu.tr

\section{INTRODUCTION}

In addition to being a renewable lignocellulosic material, wood is the most suitable material for building construction due to its relative high strength in comparison to its weight and low processing costs. However, wood has a lower dimensional stability than non-recyclable synthetic materials. This issue limits the use of wood since dimensional stability is an important criterion in many fields of application. Wood modification reduces the hygroscopic behavior of wood and is therefore necessary in order to improve its dimensional stability, as well as to boost its resistance to biological organisms, e.g., fungi and insects. Thermal (heat) treatment is performed via heating the wood without the use of any chemicals. The fact that it is not necessary to use chemicals makes it one of the most common commercial wood modification methods (Lee et al. 2018). According to Hill (2006), thermal modification should be performed at temperatures between $180^{\circ} \mathrm{C}$ and 260 ${ }^{\circ} \mathrm{C}$. While lower temperatures (below $140{ }^{\circ} \mathrm{C}$ ) cause no major changes in the properties of wood, at higher temperatures the structure of the wood is severely degraded, which causes changes to the physical and chemical properties of the wood (Yildiz et al. 2006; Candelier et al. 2013; Yang et al. 2015). An important physical property that changes at high temperatures is the color of the wood (Nemeth et al. 2016). The lignins and the chromophores contained in the extractives are responsible for the color of wood. The 
degradation of the hemicelluloses found in the wood during the heat treatment leads to the formation of new chromophores, which as a consequence, causes the color of the wood to change (Kučerová et al. 2016; Nemeth et al. 2016). The darkening of the wood surface increases with the increase in the temperature of the heat treatment.

Although the effects of the heat treatment temperature and duration on the properties of wood materials have been evaluated in various studies, research is lacking on the effects of the atmosphere under (open system) which the heat treatment is carried out (Hidayat et al. 2017). Some studies have experimented with the use of a vacuum environment (close system) as a heat treatment medium (Rep et al. 2004; Allegretti et al. 2012; Surini et al. 2012). The boiling point of water is reduced under vacuum, which causes the water to evaporate at lower heat treatment temperatures. The effects of water are reduced in the wood hydrolyzed during the heat treatment. Therefore, heat treatments performed under vacuum result in lower weight losses (Allegretti et al. 2012; Srinivas and Pandey 2012).

Although some studies have examined a heat treatment closed system, no data have been reported on the effects of such treatments on the color, glossiness, or roughness of wood coatings. The aim of this study was to determine the influence of heat treatments in a closed or open system on various surface modifications. To this purpose, the changes in surface color, glossiness, and roughness of the pine and poplar wood samples subjected to thermal treatment in both open and closed systems were investigated. In addition, after the heat treatments, the surfaces of the samples were coated with three types of coatings, i.e., water-based, polyurethane-based, and oil-based varnishes, and the strength of the surface properties of the wood samples were measured.

\section{EXPERIMENTAL}

Scots pine (Pinus sylvestris L.) and poplar (Populus euramericana) specimens were prepared from sapwood blocks with dimensions of $75 \mathrm{~mm}(\mathrm{R}) \times 15 \mathrm{~mm}(\mathrm{~T}) \times 150(\mathrm{~L}) \mathrm{mm}$. The specimens were free of macroscopic defects, e.g., knots and splits. The oven-dried densities of the pine and poplar samples used were $0.66 \mathrm{~g} \mathrm{~cm}^{-3}$ and $0.28 \mathrm{~g} \mathrm{~cm}^{-3}$, respectively.

Prior to the heat treatment, all the specimens were oven dried at $103{ }^{\circ} \mathrm{C}$ to a moisture content of $0 \%$. The oven and vacuum pressure chamber samples were subjected to heat treatment for $2 \mathrm{~h}$ at a range of $180{ }^{\circ} \mathrm{C}$ to $200{ }^{\circ} \mathrm{C}$ for the poplar samples and at a range of $190{ }^{\circ} \mathrm{C}$ to $212^{\circ} \mathrm{C}$ for the Scots pine samples. Poplar is known to be more affected by heat treatment. Therefore, the heat treatment temperature was kept lower. For the first method (open system), heat treatment was performed using an oven (Memmert, Schwabach, Germany). No water vapor or other gases were introduced into the environment. The samples were placed into the oven when the target temperature was reached. In the second method (close system), the oven-dried samples were place in a vacuum pressure chamber (Jeio Tech, Seoul, Korea) once a vacuum of $675 \mathrm{mmHg}$ was achieved. After the heat treatments, the mass loss was determined by Eq. 1,

$$
\text { Mass loss }(\%)=\left(\left(m_{1}-m_{2}\right) / m_{1}\right) \times 100
$$

where $m_{1}$ is the mass before heat treatment and $m_{2}$ is the mass after treatment. Finally, the modified samples were stored for two weeks in a controlled environment at $20{ }^{\circ} \mathrm{C}$ and $65 \%$ relative humidity $(\mathrm{RH})$. 
Three types of varnish, a water-based (AQUA), a polyurethane-based (PUR), and an oil/wax-based (OIL+WAX) varnish, were applied to the unheated (control) and heattreated samples. The varnishes were applied on the samples by hand using a roller brush with a spread rate of $100 \mathrm{~g} / \mathrm{m}^{2}$.

The color measurement was performed with a Konica Minolta spectrophotometer (Osaka, Japan) via measuring the $L^{*}, a^{*}$, and $b^{*}$ values of the samples. For each sample, three-color measurements were made at randomly selected zones, according to ISO standard 7724-2 (1984). The CIELab System was used for color evaluation. The $L^{*}, a^{*}$, and $b^{*}$ color coordinates were determined for the sample only after coating. $L^{*}$ represents the black-and-white axis; for black, $L^{*}=0$, and for white, $L^{*}=100 ; a^{*}$ represents redgreen color based on the positive and negative axes and $b^{*}$ represents yellow-blue color (positive value to yellow, negative value to blue). The changes in the color coordinates $\left(\Delta L^{*}, \Delta a^{*}\right.$, and $\left.\Delta b^{*}\right)$ were determined by taking the difference between the final (after coating) and initial (before coating) value. The total color changes $\left(\Delta E^{*}\right)$ were calculated according to Eq. 2,

$$
\Delta E^{*}=\left[\left(\Delta a^{*}\right)^{2}+\left(\Delta b^{*}\right)^{2}+\left(\Delta L^{*}\right)^{2}\right] 1 / 2
$$

where $\Delta L^{*}$ is the change in $L^{*}, \Delta \mathrm{a}^{*}$ is the change in $a^{*}$, and $\Delta b^{*}$ is the change in $b^{*}$.

The gloss levels were determined in accordance with DIN standard 67530 (1982) and ISO standard 2813 (2014) using a PICO GLOSS 503 photoelectric apparatus. The surface gloss of the heat-treated (HT) and vacuum heat-treated (VHT) samples, both coated and non-coated, were measured at $20^{\circ}, 60^{\circ}$, and $85^{\circ}$ angles of incidence. For typical test measurements, a $20^{\circ}$ angle is used to measure the surface gloss of matte coatings, a $60^{\circ}$ angle is used for both matte and glossy specimens, and an $85^{\circ}$ angle is used for very glossy surfaces. Two measurements were taken from the surface of each sample, one parallel to the grain direction (of the wood fibers) and one perpendicular to the grain direction. Five measurements in both direction parallel and perpendicular to the grain. Five measurements were taken of the surface in each direction. A complete specular light reflection, i.e., very high gloss, would be $100 \%$, and a complete diffuse light reflection, i.e., matte, would be $0 \%$.

The surface quality measurements were performed using a MicroProf FRT instrument (Fries Research \& Technology GmbH, Bergisch Gladbach, Germany). The range of roughness parameters were calculated by device, which included the arithmetic mean deviation of the assessed profile $\left(R_{\mathrm{a}}\right), R_{\mathrm{z}}$, and $R_{\mathrm{qmax}}$. All of the parameters were measured in $2 \mathrm{D}$ profile and three measurements were taken from the surface of each direction, i.e., one parallel to the grain direction and one perpendicular to the grain direction. Using an evaluation length of $50 \mathrm{~mm}$, a sampling length of $2.5 \mathrm{~mm}$, and a measuring resolution of $5 \mu \mathrm{m}$ with the scanning speed of $750 \mu \mathrm{m} / \mathrm{s}$, a total of 10000 points were scanned per measurement. A Gaussian filter was automatically applied to all roughness data. The roughness measurements were performed for all samples prior to and after being coating in their respective varnish.

\section{RESULTS AND DISCUSSION}

The mass loss values of the poplar and Scots pine samples, which were heat treated after reaching their full dry weight, are shown in Table 1. In addition, the standard deviation values are shown in parentheses. 
Table 1. Mass Loss (\%)

\begin{tabular}{|c|c|c|c|c|c|c|c|}
\hline \multicolumn{3}{|c|}{ Scots Pine (Pinus sylvestris L.) } & \multicolumn{3}{c|}{ Poplar (Populus euramericana) } \\
\hline HT-190 & HT-212 & VHT-190 & VHT-212 & HT-180 & HT-200 & VHT-180 & VHT-200 \\
\hline $2.01 \mathrm{~b}$ & $6.32 \mathrm{c}$ & $1.00 \mathrm{a}$ & $2.04 \mathrm{~b}$ & $0.54 \mathrm{a}$ & $2.31 \mathrm{~b}$ & $0.55 \mathrm{a}$ & $0.84 \mathrm{a}$ \\
$(0.25)$ & $(0.64)$ & $(0.14)$ & $(0.39)$ & $(0.11)$ & $(0.20)$ & $(0.18)$ & $(0.38)$ \\
\hline
\end{tabular}

Note: $\mathrm{HT}$ = heat-treated; VHT = vacuum heat-treated, In parentheses: SD

$a, b, c$ indicate Duncan's homogeneity groups in the column. The fact that the letters are

different shows that the variations take place in significantly different groups.

A mass loss of 2.01 to $6.32 \%$ was observed for the HT Scots pine samples treated at 190 to $212{ }^{\circ} \mathrm{C}$, and a mass loss of 0.54 to $2.31 \%$ was observed for the HT poplar samples treated at 180 to $200{ }^{\circ} \mathrm{C}$. However, lower mass loss percentages were obtained after heat treatment in a closed system. A mass loss in the range of 1.00 to $2.04 \%$ was observed in the Scots pine VHT samples, and mass loss in the range of 0.55 to $0.84 \%$ was observed in the poplar VHT samples. Mass loss is one of the most important features that changes during heat treatment. The mass loss of wood varies depending on the heat treatment medium, temperature, and duration (Esteves and Pereira 2008; Kutnar et al. 2013). For Scots pine heat treated at $210^{\circ} \mathrm{C}$, a mass loss of $13.6 \%$ was reported (Sivrikaya et al. 2015). However, for the current study, heat treatment at $212{ }^{\circ} \mathrm{C}$ resulted in a mass loss of $6.32 \%$, and at temperatures below $190^{\circ} \mathrm{C}$ was even lower (Table 1). The mass loss values of the poplar samples after heat treatment in an open and closed system were found to be lower than those of the Scots pine samples. This is attributed to the low heat treatment temperature. However, it was revealed that the wood of coniferous trees was more sensitive to heat treatment in a dry environment. The lack of oxygen during the heat treatment in a vacuum environment reduced the weight loss values. Ferrari et al. (2013) determined that weight loss values increased as an effect of a reduced vacuum medium, but at low temperatures, the amount of oxygen in the environment was not important. The results of the author's study showed that at $180{ }^{\circ} \mathrm{C}$, there was no statistically significant $(\mathrm{P}$-value $=$ 0.03 ) difference between poplar wood being subjected to heat treatment in either a closed system or an open system.

\section{Color Changes}

The color values of the Scots pine and poplar samples with three different varnishes are shown in Table 2. Color measurement was conducted on samples only after coating.

A low $\Delta E^{*}$ value indicated either little color change or color stability. For all the heat-treated variations, negative $\Delta L^{*}$ values, positive $\Delta a^{*}$ values (excluding the PUR varnish-treated Scots pine control), and positive $\Delta b^{*}$ values were obtained. The maximum total color change value for the Scots pine control samples was found in samples with an OIL + WAX varnish application $\left(\Delta E^{*}=9.85\right)$. With the application of varnishes to the heat-treated Scots pine samples, the total color-change values increased when compared to the control samples; i.e., greater color change was observed in the heat-treated samples. However, in the samples heat treated in a closed system, the total color change value was higher than the control values, but lower than the samples heat treated under a normal oxygen environment. The maximum total color change value was observed in the heattreated samples with an OIL + WAX varnish application, similar to the Scots pine control samples. In a literature study by Tomak (2011), $\Delta E^{*}$ values of 22 to 24 were found for Scots pine samples impregnated with hazelnut oil, waste oil, soybean oil, corn oil, 
sunflower oil, and canola oil. After the oil treatment, the wood samples became more yellowish-brown in color.

The poplar wood samples behaved similarly to the Scots pine wood samples; i.e., the color change values in the control samples with an application of varnish were lower than the color change values in the test samples. The fact that the color change values of the control samples were lower than the test samples was caused by the heat treatment applied to the samples. The transparent structure of the three varnish treatments caused the post-heat treatment color differences to be reflected in the measurements. The causes of the sample surface color changes after heat treatment have been noted in multiple literature studies (Tjeerdsma et al. 1998; Mitsui et al. 2001; Bekhta and Niemz, 2003; Ahajji et al. 2009; Gunduz et al. 2010; Kamperidou et al. 2013; Sivrikaya et al. 2019). Chow and Mukai (1972) stated that there is a relationship between the color change caused by heat treatment and the degree of crystallinity, degree of polymerization, and amount of $\mathrm{OH}$.

Table 2. Color Coordinates and Total Color Changes of Heat- and Vacuum HeatTreated Scots Pine and Poplar Samples after Coating

\begin{tabular}{|c|c|c|c|c|c|c|}
\hline & $\begin{array}{c}\text { Varnish } \\
\text { Type }\end{array}$ & Variation & $\Delta L$ & $\Delta a$ & $\Delta b$ & $\Delta E$ \\
\hline \multirow{15}{*}{ 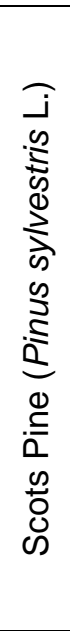 } & \multirow{5}{*}{ AQUA } & Control & $-4.22(0.50)$ & $0.33(0.29)$ & $1.09(0.63)$ & $4.41(0.60)$ \\
\hline & & HT-190 & $-6.88(1.47)$ & $1.47(0.43)$ & $5.45(0.79)$ & $9.00(0.92)$ \\
\hline & & HT-212 & $-13.63(1.58)$ & $3.00(0.54)$ & $1.81(1.73)$ & $14.19(1.20)$ \\
\hline & & VHT-190 & $-5.12(4.04)$ & $0.83(0.46)$ & $1.34(0.52)$ & $6.34(1.75)$ \\
\hline & & VHT-212 & $2.63(9.60)$ & $0.31(1.34)$ & $3.74(1.01)$ & $9.13(3.45)$ \\
\hline & \multirow{5}{*}{ PUR } & Control & $-6.08(0.97)$ & $-0.02(0.21)$ & $1.49(0.60)$ & $6.28(1.04)$ \\
\hline & & HT-190 & $-10.51(1.88)$ & $2.07(0.43)$ & $6.21(1.17)$ & $12.45(1.76)$ \\
\hline & & HT-212 & $-11.40(3.99)$ & $3.13(1.72)$ & $0.43(2.72)$ & $12.13(4.21)$ \\
\hline & & VHT-190 & $-5.23(3.73)$ & $0.95(1.22)$ & $2.80(1.23)$ & $6.24(3.68)$ \\
\hline & & VHT-212 & $-2.39(6.04)$ & $0.86(1.24)$ & $2.63(1.61)$ & $6.49(2.17)$ \\
\hline & \multirow{5}{*}{$\begin{array}{l}\text { OIL + } \\
\text { WAX }\end{array}$} & Control & $-8.14(0.43)$ & $0.91(0.17)$ & $5.43(0.86)$ & $9.85(0.64)$ \\
\hline & & HT-190 & $-14.17(2.37)$ & $4.00(1.26)$ & $10.45(0.98)$ & $18.07(2.69)$ \\
\hline & & HT-212 & $-20.40(2.35)$ & $6.72(0.79)$ & $2.40(2.51)$ & $21.77(2.07)$ \\
\hline & & VHT-190 & $-8.99(1.36)$ & $1.41(0.47)$ & $5.85(1.63)$ & $10.88(1.80)$ \\
\hline & & VHT-212 & $-22.11(9.18)$ & $5.16(1.56)$ & $8.35(1.89)$ & $24.52(8.13)$ \\
\hline \multirow{15}{*}{  } & \multirow{5}{*}{ AQUA } & Control & $-5.14(1.11)$ & $1.14(0.34)$ & $2.63(0.67)$ & $5.92(1.13)$ \\
\hline & & HT-180 & $-6.93(0.60)$ & $1.29(0.23)$ & $3.94(0.53)$ & $8.09(0.57)$ \\
\hline & & HT-200 & $-12.85(3.87)$ & $3.16(0.35)$ & $5.11(1.04)$ & $14.35(3.21)$ \\
\hline & & VHT-180 & $-5.18(0.99)$ & $1.46(0.42)$ & $3.06(1.15)$ & $6.22(1.42)$ \\
\hline & & VHT-200 & $-7.98(3.06)$ & $2.69(0.55)$ & $4.83(0.67)$ & $9.82(2.72)$ \\
\hline & \multirow{5}{*}{ PUR } & Control & $-4.29(1.92)$ & $1.51(0.54)$ & $3.80(0.30)$ & $6.08(1.38)$ \\
\hline & & HT-180 & $-5.70(2.78)$ & $1.75(0.54)$ & $4.89(1.07)$ & $7.82(2.65)$ \\
\hline & & HT-200 & $-12.73(2.83)$ & $4.21(0.62)$ & $7.58(1.76)$ & $15.60(2.07)$ \\
\hline & & VHT-180 & $-6.00(1.02)$ & $2.44(0.36)$ & $5.98(0.78)$ & $8.83(1.24)$ \\
\hline & & VHT-200 & $-10.27(2.35)$ & $3.89(0.38)$ & $6.37(1.53)$ & $12.85(1.75)$ \\
\hline & \multirow{5}{*}{$\begin{array}{l}\text { OIL + } \\
\text { WAX }\end{array}$} & Control & $-8.48(1.12)$ & $2.22(0.53)$ & $8.01(0.63)$ & $11.89(1.23)$ \\
\hline & & HT-180 & $-7.67(2.15)$ & $2.64(0.95)$ & $8.55(1.18)$ & $11.98(1.25)$ \\
\hline & & HT-200 & $-16.12(2.94)$ & $7.48(1.40)$ & $12.86(1.34)$ & $22.07(2.06)$ \\
\hline & & VHT-180 & $-8.92(2.41)$ & $3.34(0.90)$ & $9.03(1.23)$ & $13.15(2.68)$ \\
\hline & & VHT-200 & $-16.09(6.11)$ & $6.24(0.74)$ & $12.40(1.08)$ & $21.56(4.79)$ \\
\hline
\end{tabular}


The total color change values of the Scots pine samples subjected to a vacuum heat treatment were found to be lower than the samples heat treated in an oxygen environment. However, there was no significant (P-value $<5 \%$ ) difference between the vacuum heat treated and oxygen heat treated the poplar wood samples. Yang et al. (2015) applied a thermo-vacuum treatment to alder birch (Betula alnoides) hardwood at temperatures of 160 to $200{ }^{\circ} \mathrm{C}$ under a relative vacuum of $-0.08 \mathrm{MPa}$. Higher heat-treatment temperatures (180 ${ }^{\circ} \mathrm{C}$ or greater) and longer treatment times (h) resulted in lower $\Delta L^{*}$ values and higher $\Delta E^{*}$ values. The $L^{*}$ value decreased from 76.81 to 52.27 , and the highest $\Delta E^{*}$ value was 25.21 , which resulted from a heat treatment at $200{ }^{\circ} \mathrm{C}$ for $4 \mathrm{~h}$.

\section{Gloss Values}

The gloss values of the Scots pine and poplar wood samples are shown in Table 3. The measurements were made both parallel to and perpendicular to the grain of the wood. For the control samples measured at $20^{\circ}, 60^{\circ}$ and $85^{\circ}$ parallel and perpendicular to the fibers, the Scots pine samples with an OIL + WAX application yielded the highest gloss value (6.05) and the poplar samples treated with PUR yielded the lowest gloss value. At the $60^{\circ}$ and $85^{\circ}$ measurements in both directions, the same varnish applications yielded the highest and lowest gloss values.

Table 3. Average Gloss Values for Heat- and Vacuum Heat-Treated Poplar and Scots Pine Samples After Coating

\begin{tabular}{|c|c|c|c|c|c|c|c|c|}
\hline & \multicolumn{3}{|c|}{ Parallel (II) to the grain } & \multicolumn{3}{|c|}{ Perpendicular $(\perp)$ to the grain } \\
\hline & & & $20^{\circ}$ & $60^{\circ}$ & $85^{\circ}$ & $20^{\circ}$ & $60^{\circ}$ & $85^{\circ}$ \\
\hline \multirow{14}{*}{ 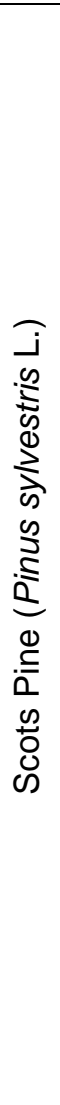 } & \multirow{5}{*}{$\begin{array}{l}\frac{\pi}{2} \\
\frac{0}{\alpha}\end{array}$} & Control & $\begin{array}{c}2.41 \\
(0.18)\end{array}$ & $\begin{array}{c}16.96 \\
(1.62)\end{array}$ & $\begin{array}{l}28.45 \\
(3.47)\end{array}$ & $\begin{array}{c}2.38 \\
(0.17)\end{array}$ & $\begin{array}{l}12.55 \\
(0.94)\end{array}$ & $\begin{array}{c}14.22 \\
(1.38)\end{array}$ \\
\hline & & HT-190 & $\begin{array}{c}2.77 \\
(0.18)\end{array}$ & $\begin{array}{l}20.65 \\
(1.42)\end{array}$ & $\begin{array}{l}35.39 \\
(2.42)\end{array}$ & $\begin{array}{c}2.63 \\
(0.16)\end{array}$ & $\begin{array}{l}14.95 \\
(0.87)\end{array}$ & $\begin{array}{l}19.72 \\
(2.33)\end{array}$ \\
\hline & & HT-212 & $\begin{array}{c}2.49 \\
(0.33)\end{array}$ & $\begin{array}{l}19.48 \\
(1.80)\end{array}$ & $\begin{array}{l}35.77 \\
(3.52)\end{array}$ & $\begin{array}{c}2.55 \\
(0.23)\end{array}$ & $\begin{array}{l}16.39 \\
(1.52)\end{array}$ & $\begin{array}{l}23.37 \\
(2.80)\end{array}$ \\
\hline & & VHT-190 & $\begin{array}{c}2.20 \\
(0.23)\end{array}$ & $\begin{array}{l}16.51 \\
(1.97)\end{array}$ & $\begin{array}{l}27.76 \\
(3.23)\end{array}$ & $\begin{array}{c}2.17 \\
(0.20)\end{array}$ & $\begin{array}{l}12.35 \\
(0.93)\end{array}$ & $\begin{array}{r}14.59 \\
(1.93)\end{array}$ \\
\hline & & VHT-212 & $\begin{array}{c}2.53 \\
(0.32)\end{array}$ & $\begin{array}{l}19.87 \\
(2.05)\end{array}$ & $\begin{array}{l}35.15 \\
(3.97)\end{array}$ & $\begin{array}{c}2.42 \\
(0.34)\end{array}$ & $\begin{array}{l}14.85 \\
(1.27)\end{array}$ & $\begin{array}{l}19.62 \\
(2.10)\end{array}$ \\
\hline & \multirow{5}{*}{$\stackrel{\Upsilon}{\frac{1}{0}}$} & Control & $\begin{array}{c}2.25 \\
(0.74)\end{array}$ & $\begin{array}{l}14.22 \\
(5.08)\end{array}$ & $\begin{array}{l}19.34 \\
(8.53)\end{array}$ & $\begin{array}{c}2.38 \\
(0.61)\end{array}$ & $\begin{array}{l}12.85 \\
(3.69)\end{array}$ & $\begin{array}{l}15.16 \\
(5.31)\end{array}$ \\
\hline & & $\mathrm{HT}-190$ & $\begin{array}{c}2.04 \\
(0.44)\end{array}$ & $\begin{array}{l}13.57 \\
(2.62)\end{array}$ & $\begin{array}{l}19.12 \\
(5.12)\end{array}$ & $\begin{array}{c}2.47 \\
(0.37)\end{array}$ & $\begin{array}{l}13.49 \\
(2.23)\end{array}$ & $\begin{array}{l}14.40 \\
(2.54)\end{array}$ \\
\hline & & HT-212 & $\begin{array}{c}1.78 \\
(0.44)\end{array}$ & $\begin{array}{r}13.79 \\
(3.80)\end{array}$ & $\begin{array}{l}23.92 \\
(8.00)\end{array}$ & $\begin{array}{c}1.64 \\
(0.49)\end{array}$ & $\begin{array}{l}11.42 \\
(3.04)\end{array}$ & $\begin{array}{l}16.74 \\
(3.97)\end{array}$ \\
\hline & & VHT-190 & $\begin{array}{r}1.65 \\
(0.20) \\
\end{array}$ & $\begin{array}{r}11.00 \\
(1.48)\end{array}$ & $\begin{array}{r}14.82 \\
(2.98) \\
\end{array}$ & $\begin{array}{c}1.50 \\
(0.38) \\
\end{array}$ & $\begin{array}{c}8.27 \\
(2.51) \\
\end{array}$ & $\begin{array}{c}9.96 \\
(2.96)\end{array}$ \\
\hline & & VHT-212 & $\begin{array}{c}1.20 \\
(0.05)\end{array}$ & $\begin{array}{c}8.59 \\
(0.83)\end{array}$ & $\begin{array}{l}14.60 \\
(2.01)\end{array}$ & $\begin{array}{c}1.18 \\
(0.32)\end{array}$ & $\begin{array}{c}7.24 \\
(2.44)\end{array}$ & $\begin{array}{c}9.92 \\
(3.53)\end{array}$ \\
\hline & \multirow{4}{*}{\begin{tabular}{l}
$\stackrel{x}{3}$ \\
+ \\
+ \\
\multirow{3}{*}{}
\end{tabular}} & Control & $\begin{array}{c}6.05 \\
(1.23)\end{array}$ & $\begin{array}{l}38.81 \\
(4.93)\end{array}$ & $\begin{array}{l}60.36 \\
(7.27)\end{array}$ & $\begin{array}{c}5.85 \\
(2.00)\end{array}$ & $\begin{array}{l}30.30 \\
(8.24)\end{array}$ & $\begin{array}{c}42.95 \\
(11.19)\end{array}$ \\
\hline & & HT-190 & $\begin{array}{c}4.64 \\
(0.76)\end{array}$ & $\begin{array}{l}32.16 \\
(4.56)\end{array}$ & $\begin{array}{l}48.50 \\
(8.17)\end{array}$ & $\begin{array}{c}4.53 \\
(1.14)\end{array}$ & $\begin{array}{l}24.82 \\
(4.58)\end{array}$ & $\begin{array}{l}33.99 \\
(7.23)\end{array}$ \\
\hline & & HT-212 & $\begin{array}{c}4.52 \\
(0.78)\end{array}$ & $\begin{array}{l}31.97 \\
(4.31)\end{array}$ & $\begin{array}{l}48.24 \\
(8.77)\end{array}$ & $\begin{array}{c}4.54 \\
(1.33)\end{array}$ & $\begin{array}{l}25.57 \\
(5.29)\end{array}$ & $\begin{array}{l}35.52 \\
(7.06)\end{array}$ \\
\hline & & VHT-190 & 3.56 & 26.90 & 40.42 & 4.02 & 22.24 & 28.20 \\
\hline
\end{tabular}




\begin{tabular}{|c|c|c|c|c|c|c|c|c|}
\hline & & & $(0.79)$ & (5.35) & (9.37) & $(1.30)$ & (6.59) & (9.39) \\
\hline & & VHT-212 & $\begin{array}{c}3.90 \\
(1.34)\end{array}$ & $\begin{array}{l}28.82 \\
(6.69)\end{array}$ & $\begin{array}{l}43.80 \\
(4.77)\end{array}$ & $\begin{array}{c}4.43 \\
(1.38)\end{array}$ & $\begin{array}{l}24.88 \\
(5.94)\end{array}$ & $\begin{array}{l}34.69 \\
(8.84)\end{array}$ \\
\hline \multirow{15}{*}{ 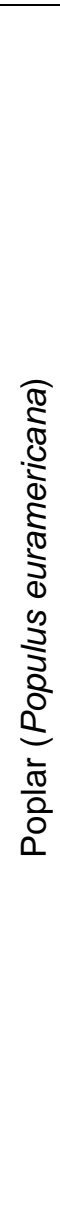 } & \multirow{5}{*}{$\begin{array}{l}\frac{\pi}{2} \\
\frac{0}{\alpha}\end{array}$} & Control & $\begin{array}{c}2.56 \\
(0.25)\end{array}$ & $\begin{array}{r}18.30 \\
(1.62)\end{array}$ & $\begin{array}{l}29.55 \\
(3.16)\end{array}$ & $\begin{array}{c}2.49 \\
(0.47)\end{array}$ & $\begin{array}{l}14.43 \\
(2.32)\end{array}$ & $\begin{array}{l}19.14 \\
(4.51)\end{array}$ \\
\hline & & HT-180 & $\begin{array}{c}1.55 \\
(0.39) \\
\end{array}$ & $\begin{array}{r}13.27 \\
(2.56) \\
\end{array}$ & $\begin{array}{l}20.85 \\
(4.80) \\
\end{array}$ & $\begin{array}{c}1.48 \\
(0.35) \\
\end{array}$ & $\begin{array}{r}11.19 \\
(1.55) \\
\end{array}$ & $\begin{array}{l}16.15 \\
(2.35) \\
\end{array}$ \\
\hline & & HT-200 & $\begin{array}{c}2.03 \\
(0.30)\end{array}$ & $\begin{array}{c}17.77 \\
(1.50)\end{array}$ & $\begin{array}{l}32.51 \\
(4.08)\end{array}$ & $\begin{array}{c}2.00 \\
(0.29)\end{array}$ & $\begin{array}{l}14.67 \\
(1.36)\end{array}$ & $\begin{array}{l}24.30 \\
(2.86)\end{array}$ \\
\hline & & VHT-180 & $\begin{array}{c}2.68 \\
(0.36)\end{array}$ & $\begin{array}{l}21.26 \\
(1.55)\end{array}$ & $\begin{array}{l}36.46 \\
(2.37)\end{array}$ & $\begin{array}{c}2.79 \\
(0.24)\end{array}$ & $\begin{array}{l}14.73 \\
(2.74)\end{array}$ & $\begin{array}{l}21.44 \\
(3.72)\end{array}$ \\
\hline & & VHT-200 & $\begin{array}{c}2.50 \\
(0.32)\end{array}$ & $\begin{array}{l}19.17 \\
(2.14)\end{array}$ & $\begin{array}{l}30.74 \\
(4.36)\end{array}$ & $\begin{array}{c}2.41 \\
(0.48)\end{array}$ & $\begin{array}{r}15.28 \\
(1.80)\end{array}$ & $\begin{array}{l}22.09 \\
(3.16)\end{array}$ \\
\hline & \multirow{5}{*}{$\stackrel{\frac{9}{\partial}}{\square}$} & Control & $\begin{array}{c}1.85 \\
(0.34)\end{array}$ & $\begin{array}{c}10.70 \\
(2.69)\end{array}$ & $\begin{array}{l}12.45 \\
(2.76)\end{array}$ & $\begin{array}{c}2.02 \\
(0.33)\end{array}$ & $\begin{array}{l}10.11 \\
(2.30)\end{array}$ & $\begin{array}{l}10.44 \\
(3.36)\end{array}$ \\
\hline & & HТ-180 & $\begin{array}{c}1.26 \\
(0.40)\end{array}$ & $\begin{array}{c}8.77 \\
(3.98) \\
\end{array}$ & $\begin{array}{l}18.10 \\
(8.00)\end{array}$ & $\begin{array}{c}1.45 \\
(0.45)\end{array}$ & $\begin{array}{c}8.63 \\
(2.88) \\
\end{array}$ & $\begin{array}{r}10.05 \\
(3.51)\end{array}$ \\
\hline & & HT-200 & $\begin{array}{c}0.63 \\
(0.25)\end{array}$ & $\begin{array}{r}5.76 \\
(2.08)\end{array}$ & $\begin{array}{l}11.63 \\
(3.63)\end{array}$ & $\begin{array}{c}1.00 \\
(0.38)\end{array}$ & $\begin{array}{c}7.93 \\
(2.53) \\
\end{array}$ & $\begin{array}{l}12.16 \\
(3.02)\end{array}$ \\
\hline & & VHT-180 & $\begin{array}{r}1.57 \\
(0.53) \\
\end{array}$ & $\begin{array}{r}9.35 \\
(4.22) \\
\end{array}$ & $\begin{array}{l}10.21 \\
(7.05)\end{array}$ & $\begin{array}{c}1.38 \\
(0.20) \\
\end{array}$ & $\begin{array}{r}6.79 \\
(1.23) \\
\end{array}$ & $\begin{array}{r}6.45 \\
(2.72) \\
\end{array}$ \\
\hline & & VHT-200 & $\begin{array}{c}0.99 \\
(0.17)\end{array}$ & $\begin{array}{r}5.35 \\
(1.30)\end{array}$ & $\begin{array}{c}5.08 \\
(2.73)\end{array}$ & $\begin{array}{c}0.99 \\
(0.28)\end{array}$ & $\begin{array}{c}4.84 \\
(1.84)\end{array}$ & $\begin{array}{c}4.91 \\
(2.99)\end{array}$ \\
\hline & \multirow{5}{*}{$\begin{array}{l}\stackrel{\times}{3} \\
+ \\
+ \\
0\end{array}$} & Control & $\begin{array}{c}4.60 \\
(0.81)\end{array}$ & $\begin{array}{l}32.57 \\
(4.69)\end{array}$ & $\begin{array}{l}43.23 \\
(6.55)\end{array}$ & $\begin{array}{c}4.23 \\
(0.77)\end{array}$ & $\begin{array}{l}22.77 \\
(2.85)\end{array}$ & $\begin{array}{l}29.99 \\
(4.06)\end{array}$ \\
\hline & & HT-180 & $\begin{array}{c}4.71 \\
(0.96)\end{array}$ & $\begin{array}{l}33.58 \\
(4.14)\end{array}$ & $\begin{array}{l}54.18 \\
(5.93)\end{array}$ & $\begin{array}{c}4.17 \\
(0.55)\end{array}$ & $\begin{array}{l}24.46 \\
(2.71)\end{array}$ & $\begin{array}{l}36.85 \\
(4.00)\end{array}$ \\
\hline & & HT-200 & $\begin{array}{c}3.96 \\
(0.58)\end{array}$ & $\begin{array}{l}29.53 \\
(3.28)\end{array}$ & $\begin{array}{l}50.87 \\
(4.52)\end{array}$ & $\begin{array}{c}3.82 \\
(0.83)\end{array}$ & $\begin{array}{l}24.67 \\
(4.09)\end{array}$ & $\begin{array}{l}41.13 \\
(3.70)\end{array}$ \\
\hline & & VHT-180 & $\begin{array}{c}2.90 \\
(0.38)\end{array}$ & $\begin{array}{l}22.78 \\
(3.65)\end{array}$ & $\begin{array}{l}29.52 \\
(4.92)\end{array}$ & $\begin{array}{c}3.04 \\
(0.43)\end{array}$ & $\begin{array}{l}15.92 \\
(2.68)\end{array}$ & $\begin{array}{l}15.10 \\
(2.58)\end{array}$ \\
\hline & & VHT-200 & $\begin{array}{c}3.08 \\
(0.64)\end{array}$ & $\begin{array}{l}22.83 \\
(3.96)\end{array}$ & $\begin{array}{l}30.70 \\
(7.58)\end{array}$ & $\begin{array}{c}3.36 \\
(0.44) \\
\end{array}$ & $\begin{array}{l}19.68 \\
(2.11)\end{array}$ & $\begin{array}{l}26.70 \\
(4.11)\end{array}$ \\
\hline
\end{tabular}

The gloss values of the Scots pine and poplar wood samples were found to generally decrease with heat treatment and coatings (as shown in Table 3). Moreover, the gloss values decreased in parallel with an increase in the heat treatment temperature. The results obtained were similar to those in multiple literature studies (Korkut et al. 2013; Krystofiak et al. 2014; Ayata et al. 2017). Furthermore, the gloss values of the samples heat-treated in a closed system were lower than the samples heat-treated in oxygen (except for the poplar samples with an AQUA or PUR varnish).

The glossiness was generally higher parallel to the grain than perpendicular to the grain, which was in accordance with the prior report by Bekhta et al. (2014). For gloss measurements made perpendicular to the grain, the device prevented light reflection as the measuring light struck the fibers. This resulted in lower gloss values for the wood samples.

\section{Surface Roughness Values}

The roughness values of the samples were investigated using three different varnish surface treatments. According to the findings, the roughness values of all the poplar samples treated with an AQUA water-based varnish showed similar results; i.e., there was no statistically significant $(\mathrm{P}$-value $=0.03)$ difference between the control and the heat- 
treated samples. Greater roughness values were observed for the VHT-180 ${ }^{\circ} \mathrm{C}$ poplar samples and the VHT-212 ${ }^{\circ} \mathrm{C}$ Scots pine samples treated with a PUR varnish.

The poplar and Scots pine samples treated with an OIL + WAX varnish exhibited different behaviors. Although in general the $R_{\max }$ roughness value increased significantly (P-value $=0.03)$ for the heat-treated samples, a few of the Scots pine samples had a decreased $R_{\max }$ value. The roughness values of the Scots pine samples decreased after heat treatment in a normal oxygen environment, whereas they increased in a closed system; i.e., with an OIL + WAX varnish, the control samples (pine) and the VHT samples had the same roughness values.

The poplar and Scots pine control samples had an $R_{\mathrm{a}}$ roughness value of 1.26 and 1.04 with an AQUA varnish, 1.43 and 2.01 with a PUR varnish, and 0.43 and 0.94 with an OIL + WAX varnish, respectively. In the author's study, higher roughness values were obtained with measurements perpendicular to the grain compared to measurements parallel to the grain (Table 4).

Similar results have been reported (Gurleyen et al. 2017; Ayata and Cakıcier 2018; Ayata et al. 2018). Although there is no difference between the $R_{\text {a }}$ parameter of treated and untreated wood, this parameter is higher for wood with a two-layer coating. According to literature results, $R_{\mathrm{a}}, R_{\mathrm{Z}}$, and $R_{\mathrm{q}}$ parameters decreased for Scots pine after heat treatment (Korkut et al. 2013). These decreases can be explained by hemicellulose degradation in the cell wall and due to the high temperature applied (Feist and Sell 1987).

Table 4. Average Surface Roughness Values of Heat- and Vacuum HeatTreated Scots Pine and Poplar Samples After Coating

\begin{tabular}{|c|c|c|c|c|c|c|c|c|}
\hline & \multicolumn{3}{|c|}{ Parallel $(\|)$ to the Grain } & \multicolumn{3}{|c|}{ Perpendicular $(\perp)$ to the Grain } \\
\hline & & & $\mathrm{R}_{\mathrm{a}}$ & $\mathrm{R}_{\mathrm{z}}$ & $R_{\max }$ & $\mathrm{R}_{\mathrm{a}}$ & $\mathrm{R}_{\mathrm{z}}$ & $R_{\max }$ \\
\hline \multirow{13}{*}{ 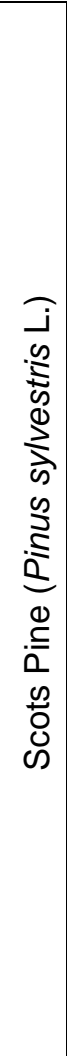 } & \multirow{5}{*}{ 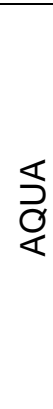 } & Control & $\begin{array}{c}1.04 \\
(0.16)\end{array}$ & $\begin{array}{c}6.00 \\
(1.00)\end{array}$ & $\begin{array}{c}9.56 \\
(4.72)\end{array}$ & $\begin{array}{c}1.57 \\
(0.26)\end{array}$ & $\begin{array}{c}8.28 \\
(1.54)\end{array}$ & $\begin{array}{l}12.02 \\
(4.51)\end{array}$ \\
\hline & & HТ-190 & $\begin{array}{c}1.56 \\
(0.53)\end{array}$ & $\begin{array}{c}8.38 \\
(2.46)\end{array}$ & $\begin{array}{l}10.10 \\
(2.88)\end{array}$ & $\begin{array}{c}1.86 \\
(0.23)\end{array}$ & $\begin{array}{l}10.11 \\
(0.88)\end{array}$ & $\begin{array}{l}15.27 \\
(2.90)\end{array}$ \\
\hline & & HT-212 & $\begin{array}{c}1.00 \\
(0.22)\end{array}$ & $\begin{array}{c}6.20 \\
(1.16)\end{array}$ & $\begin{array}{r}10.73 \\
(5.34)\end{array}$ & $\begin{array}{c}1.47 \\
(0.22)\end{array}$ & $\begin{array}{c}8.23 \\
(1.72)\end{array}$ & $\begin{array}{l}10.60 \\
(2.41)\end{array}$ \\
\hline & & VHT-190 & $\begin{array}{c}0.81 \\
(0.21)\end{array}$ & $\begin{array}{c}4.73 \\
(0.99)\end{array}$ & $\begin{array}{c}7.19 \\
(3.14)\end{array}$ & $\begin{array}{c}1.49 \\
(0.31)\end{array}$ & $\begin{array}{c}7.55 \\
(1.66)\end{array}$ & $\begin{array}{l}10.33 \\
(2.63)\end{array}$ \\
\hline & & VHT-212 & $\begin{array}{c}1.07 \\
(0.09)\end{array}$ & $\begin{array}{c}6.63 \\
(1.48)\end{array}$ & $\begin{array}{c}9.51 \\
(1.61)\end{array}$ & $\begin{array}{c}1.45 \\
(0.45)\end{array}$ & $\begin{array}{c}7.93 \\
(2.50)\end{array}$ & $\begin{array}{l}10.53 \\
(4.06)\end{array}$ \\
\hline & \multirow{5}{*}{$\stackrel{\Upsilon 9}{\frac{9}{2}}$} & Control & $\begin{array}{c}2.01 \\
(0.71)\end{array}$ & $\begin{array}{l}11.01 \\
(4.00)\end{array}$ & $\begin{array}{l}16.03 \\
(6.73)\end{array}$ & $\begin{array}{c}2.57 \\
(0.44)\end{array}$ & $\begin{array}{l}16.29 \\
(4.03)\end{array}$ & $\begin{array}{l}20.13 \\
(5.62)\end{array}$ \\
\hline & & HТ-190 & $\begin{array}{c}1.48 \\
(0.36)\end{array}$ & $\begin{array}{c}8.52 \\
(1.84)\end{array}$ & $\begin{array}{l}11.13 \\
(2.49)\end{array}$ & $\begin{array}{c}3.34 \\
(0.79)\end{array}$ & $\begin{array}{l}20.82 \\
(5.73)\end{array}$ & $\begin{array}{l}28.12 \\
(7.90)\end{array}$ \\
\hline & & HT-212 & $\begin{array}{c}1.47 \\
(0.49)\end{array}$ & $\begin{array}{c}7.82 \\
(2.47)\end{array}$ & $\begin{array}{l}10.67 \\
(3.51)\end{array}$ & $\begin{array}{c}2.52 \\
(0.18)\end{array}$ & $\begin{array}{l}15.30 \\
(2.25)\end{array}$ & $\begin{array}{l}20.69 \\
(3.76)\end{array}$ \\
\hline & & VHT-190 & $\begin{array}{c}2.66 \\
(1.03)\end{array}$ & $\begin{array}{l}15.83 \\
(5.83)\end{array}$ & $\begin{array}{l}20.74 \\
(3.76)\end{array}$ & $\begin{array}{c}3.35 \\
(1.04)\end{array}$ & $\begin{array}{l}19.74 \\
(4.43)\end{array}$ & $\begin{array}{l}27.27 \\
(4.66)\end{array}$ \\
\hline & & VHT-212 & $\begin{array}{c}3.81 \\
(0.75)\end{array}$ & $\begin{array}{l}24.01 \\
(6.53)\end{array}$ & $\begin{array}{l}31.68 \\
(6.69)\end{array}$ & $\begin{array}{c}3.16 \\
(0.66)\end{array}$ & $\begin{array}{l}21.92 \\
(5.71)\end{array}$ & $\begin{array}{l}31.37 \\
(8.22)\end{array}$ \\
\hline & \multirow{3}{*}{$\begin{array}{l}\stackrel{x}{3} \\
+ \\
+ \\
0\end{array}$} & Control & $\begin{array}{c}0.94 \\
(0.18)\end{array}$ & $\begin{array}{c}6.24 \\
(1.61)\end{array}$ & $\begin{array}{l}11.22 \\
(3.65)\end{array}$ & $\begin{array}{c}1.26 \\
(0.25)\end{array}$ & $\begin{array}{c}7.16 \\
(1.49)\end{array}$ & $\begin{array}{c}10.22 \\
(3.47)\end{array}$ \\
\hline & & HT-190 & $\begin{array}{c}0.72 \\
(0.36)\end{array}$ & $\begin{array}{c}4.00 \\
(1.99)\end{array}$ & $\begin{array}{c}5.18 \\
(2.54)\end{array}$ & $\begin{array}{c}1.20 \\
(0.42)\end{array}$ & $\begin{array}{c}7.11 \\
(3.32)\end{array}$ & $\begin{array}{l}11.37 \\
(7.56)\end{array}$ \\
\hline & & HT-212 & $\begin{array}{c}0.63 \\
(0.10)\end{array}$ & $\begin{array}{c}3.62 \\
(0.47)\end{array}$ & $\begin{array}{c}5.33 \\
(1.29)\end{array}$ & $\begin{array}{c}0.78 \\
(0.07)\end{array}$ & $\begin{array}{c}4.53 \\
(0.42)\end{array}$ & $\begin{array}{c}7.46 \\
(1.59)\end{array}$ \\
\hline
\end{tabular}




\begin{tabular}{|c|c|c|c|c|c|c|c|c|}
\hline & & VHT-190 & $\begin{array}{c}1.13 \\
(0.45)\end{array}$ & $\begin{array}{c}5.96 \\
(3.68) \\
\end{array}$ & $\begin{array}{l}11.96 \\
(6.05)\end{array}$ & $\begin{array}{c}2.10 \\
(0.27) \\
\end{array}$ & $\begin{array}{r}13.00 \\
(1.24)\end{array}$ & $\begin{array}{l}20.59 \\
(8.66) \\
\end{array}$ \\
\hline & & VHT-212 & $\begin{array}{c}1.31 \\
(0.44)\end{array}$ & $\begin{array}{c}7.36 \\
(2.20)\end{array}$ & $\begin{array}{l}11.80 \\
(4.82)\end{array}$ & $\begin{array}{c}1.60 \\
(0.39)\end{array}$ & $\begin{array}{l}10.12 \\
(3.86)\end{array}$ & $\begin{array}{l}15.54 \\
(6.68)\end{array}$ \\
\hline \multirow{15}{*}{ 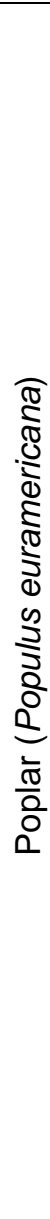 } & \multirow{5}{*}{$\begin{array}{l}\frac{1}{2} \\
\stackrel{0}{\alpha}\end{array}$} & Control & $\begin{array}{c}1.26 \\
(0.55)\end{array}$ & $\begin{array}{c}6.58 \\
(1.94)\end{array}$ & $\begin{array}{l}11.99 \\
(7.55)\end{array}$ & $\begin{array}{c}2.96 \\
(0.52)\end{array}$ & $\begin{array}{l}15.84 \\
(3.04)\end{array}$ & $\begin{array}{l}24.63 \\
(2.76)\end{array}$ \\
\hline & & HT-180 & $\begin{array}{c}1.08 \\
(0.38)\end{array}$ & $\begin{array}{c}6.36 \\
(2.11)\end{array}$ & $\begin{array}{l}12.35 \\
(5.31)\end{array}$ & $\begin{array}{c}2.15 \\
(0.26)\end{array}$ & $\begin{array}{r}11.74 \\
(1.66)\end{array}$ & $\begin{array}{l}15.78 \\
(2.57)\end{array}$ \\
\hline & & HT-200 & $\begin{array}{c}0.91 \\
(0.32)\end{array}$ & $\begin{array}{c}4.81 \\
(1.36)\end{array}$ & $\begin{array}{c}8.47 \\
(4.15)\end{array}$ & $\begin{array}{c}1.68 \\
(0.34)\end{array}$ & $\begin{array}{l}11.06 \\
(1.80)\end{array}$ & $\begin{array}{l}19.17 \\
(4.85)\end{array}$ \\
\hline & & VHT-180 & $\begin{array}{c}1.07 \\
(0.20)\end{array}$ & $\begin{array}{c}5.90 \\
(0.28)\end{array}$ & $\begin{array}{c}8.58 \\
(0.96)\end{array}$ & $\begin{array}{c}3.03 \\
(1.36)\end{array}$ & $\begin{array}{l}15.77 \\
(5.18)\end{array}$ & $\begin{array}{l}22.70 \\
(9.83)\end{array}$ \\
\hline & & VHT-200 & $\begin{array}{c}1.22 \\
(0.40)\end{array}$ & $\begin{array}{c}7.09 \\
(2.00)\end{array}$ & $\begin{array}{r}11.59 \\
(3.99)\end{array}$ & $\begin{array}{c}2.70 \\
(1.09)\end{array}$ & $\begin{array}{l}14.04 \\
(6.96)\end{array}$ & $\begin{array}{l}19.08 \\
(9.74)\end{array}$ \\
\hline & \multirow{5}{*}{$\stackrel{\Upsilon}{\frac{9}{2}}$} & Control & $\begin{array}{c}1.43 \\
(0.51)\end{array}$ & $\begin{array}{c}9.19 \\
(3.07)\end{array}$ & $\begin{array}{l}14.71 \\
(9.21)\end{array}$ & $\begin{array}{c}3.02 \\
(0.20)\end{array}$ & $\begin{array}{r}18.94 \\
(2.67)\end{array}$ & $\begin{array}{l}28.27 \\
(6.58)\end{array}$ \\
\hline & & HT-180 & $\begin{array}{c}1.69 \\
(0.65)\end{array}$ & $\begin{array}{c}9.51 \\
(4.16)\end{array}$ & $\begin{array}{l}15.74 \\
(3.19)\end{array}$ & $\begin{array}{c}2.64 \\
(0.62)\end{array}$ & $\begin{array}{l}17.70 \\
(4.85)\end{array}$ & $\begin{array}{l}26.59 \\
(8.31)\end{array}$ \\
\hline & & HT-200 & $\begin{array}{c}1.33 \\
(0.31)\end{array}$ & $\begin{array}{c}7.92 \\
(2.26)\end{array}$ & $\begin{array}{l}12.34 \\
(8.52)\end{array}$ & $\begin{array}{c}1.68 \\
(0.37)\end{array}$ & $\begin{array}{l}10.45 \\
(2.04)\end{array}$ & $\begin{array}{l}16.04 \\
(2.41)\end{array}$ \\
\hline & & VHT-180 & $\begin{array}{c}2.47 \\
(0.59)\end{array}$ & $\begin{array}{l}14.26 \\
(3.65)\end{array}$ & $\begin{array}{l}24.62 \\
(8.00)\end{array}$ & $\begin{array}{c}3.16 \\
(0.89)\end{array}$ & $\begin{array}{l}25.75 \\
(4.94)\end{array}$ & $\begin{array}{l}37.95 \\
(5.56)\end{array}$ \\
\hline & & VHT-200 & $\begin{array}{c}1.57 \\
(0.15)\end{array}$ & $\begin{array}{c}9.69 \\
(2.03)\end{array}$ & $\begin{array}{l}19.60 \\
(0.88)\end{array}$ & $\begin{array}{c}3.14 \\
(1.36)\end{array}$ & $\begin{array}{l}20.45 \\
(7.00)\end{array}$ & $\begin{array}{l}26.40 \\
(8.08)\end{array}$ \\
\hline & \multirow{5}{*}{$\begin{array}{l}\stackrel{\times}{3} \\
+ \\
+ \\
0\end{array}$} & Control & $\begin{array}{c}0.43 \\
(0.09)\end{array}$ & $\begin{array}{c}2.53 \\
(0.37)\end{array}$ & $\begin{array}{c}3.85 \\
(0.12)\end{array}$ & $\begin{array}{c}0.96 \\
(0.43)\end{array}$ & $\begin{array}{c}6.76 \\
(3.36)\end{array}$ & $\begin{array}{l}11.47 \\
(7.14)\end{array}$ \\
\hline & & HT-180 & $\begin{array}{c}1.12 \\
(0.71)\end{array}$ & $\begin{array}{c}5.43 \\
(3.27)\end{array}$ & $\begin{array}{l}16.83 \\
(9.99)\end{array}$ & $\begin{array}{c}1.26 \\
(0.12)\end{array}$ & $\begin{array}{c}9.35 \\
(2.11)\end{array}$ & $\begin{array}{l}24.85 \\
(9.11)\end{array}$ \\
\hline & & HT-200 & $\begin{array}{c}0.89 \\
(0.48)\end{array}$ & $\begin{array}{c}5.49 \\
(2.83)\end{array}$ & $\begin{array}{c}9.38 \\
(4.84)\end{array}$ & $\begin{array}{c}2.48 \\
(1.18)\end{array}$ & $\begin{array}{l}15.94 \\
(6.46)\end{array}$ & $\begin{array}{l}25.87 \\
(8.03)\end{array}$ \\
\hline & & VHT-180 & $\begin{array}{c}1.19 \\
(0.63)\end{array}$ & $\begin{array}{c}6.97 \\
(3.40)\end{array}$ & $\begin{array}{c}15.05 \\
(10.00)\end{array}$ & $\begin{array}{c}1.81 \\
(0.57)\end{array}$ & $\begin{array}{r}12.16 \\
(3.84)\end{array}$ & $\begin{array}{r}19.98 \\
(8.53)\end{array}$ \\
\hline & & VHT-200 & $\begin{array}{c}0.74 \\
(0.34)\end{array}$ & $\begin{array}{c}4.19 \\
(1.68)\end{array}$ & $\begin{array}{c}8.03 \\
(4.18)\end{array}$ & $\begin{array}{c}1.13 \\
(0.45)\end{array}$ & $\begin{array}{c}8.61 \\
(4.55)\end{array}$ & $\begin{array}{l}14.05 \\
(9.57)\end{array}$ \\
\hline
\end{tabular}

\section{CONCLUSIONS}

1. Generally, lower weight loss values were obtained for the poplar and Scots pine sapwood samples after treatment. However, vacuum heat treatment reduced the total mass loss more than heat treatment did. Therefore, it could be concluded that the process in the present study (which focused on the goal of reducing the total mass loss in the modified samples) was successful and played an important role in improving the strength properties of the sapwood samples without any damage.

2. The color change was inhibited as a result of a closed system. The total color change $\left(\Delta E^{*}\right)$ values were greater for the open system samples than for the closed system samples in Scots Pine (Pinus sylvestris L.). There was no significant difference in poplar samples. Low color changes in the closed system can be accepted as an advantage for the place of use. However, other characteristics of the wood should be considered. 
3. The gloss measurements that were taken at $20^{\circ}, 60^{\circ}$, and $85^{\circ}$ angles yielded the highest values for the poplar and Scots pine samples treated with an OIL + WAX varnish. The gloss values taken in parallel to the grain were higher than those taken perpendicular to the grain. It is recommended to use OIL + WAX applied samples in places where higher brightness is desired.

4. The three different varnish applications resulted in differences in the surface roughness values for the Scots pine and poplar wood samples. The maximum roughness value was obtained with a PUR varnish and the minimum roughness value was obtained with an OIL + WAX application. The roughness values perpendicular to the grain were greater than the roughness values parallel to the grain.

\section{ACKNOWLEDGMENTS}

The author would like to thank the COST Action FP1407 "Understanding wood modification through an integrated scientific and environmental impact approach (ModWoodLife)" for financial support within the framework of the Short Term Scientific Mission (STSM). The author would also like to thank Dr. Tomasz Krystofiak and Barbara Lis for their scientific and technical assistance in this study by preparing the wood samples for color, gloss, and roughness testing.

\section{REFERENCES CITED}

Ahajji, A., Diouf, P. N., Aloui, F., Elbakali, I., Perrin, D., Merlin, A., and George, B. (2009). "Influence of heat treatment on antioxidant properties and colour stability of beech and spruce wood and their extractives," Wood Science and Technology 43(69), 69-83. DOI: 10.1007/s00226-008-0208-3

Allegretti, O., Brunetti, M., Cuccui, I., Ferrari, S., Nocetti, M., and Terziev, N. (2012). "Thermo-vacuum modification of spruce (Picea abies Karst.) and fir (Abies alba Mill.) wood," BioResources 7(3), 656-669.

Ayata, U., Gurleyen, L., and Esteves, B. (2017). "Effect of heat treatment on the surface of selected exotic wood species," Drewno 60(199), 105-116. DOI:

10.12841/wood.1644-3985.198.08

Ayata, Ü., and Çakıcıer, N., (2018). "Determination of surface roughness against the effect of accelerated UV aging on water-based varnish applied and heat treated wood materials according to ThermoWood method," Gümüşhane University Journal of Science and Technology Institute 8(1), 122-134. DOI: 10.17714/gumusfenbil.314186.

Ayata, U., Gurleyen, T., and Gurleyen, L., and Cakicier, N., (2018). "Determination of surface roughness parameters of heat-treated and untreated scotch pine, oak and beech woods," Furniture and Wooden Material Research Journal 1(1), 46-50. DOI: $10.33725 / \mathrm{mamad} .433945$.

Bekhta, P., and Niemz, P. (2003). "Effect of high temperature on the change in color, dimensional stability and mechanical properties of spruce wood," Holzforschung 57(5), 539-546. DOI: 10.1515/HF.2003.080 
Bekhta, P., Proszyk, S., Lis, B., and Krystofiak, T. (2014). "Gloss of thermally densified alder (Alnus glutinosa Goertn.), beech (Fagus sylvatica L.), birch (Betula verrucosa Ehrh.), and pine (Pinus sylvestris L.) wood veneers," European Journal of Wood and Wood Products 72, 799-808. DOI: 10.1007/s00107-014-0843-3

Candelier, K., Dumarçay, S., Pétrissans, A., Desharnais, L., Gérardin, P., and Pétrissans, M. (2013). "Comparison of chemical composition and decay durability of heat treated wood cured under different inert atmospheres: Nitrogen or vacuum," Polymer Degradation and Stability 98(2), 677-681. DOI:

10.1016/j.polymdegradstab.2012.10.022

Chow, S. Z., and Mukai, H. N. (1972). "Effect of thermal degradation of cellulose on wood polymer bonding," Wood Science 4(4), 202-208.

DIN 67530 (1982). "Reflectometer as a means for gloss assessment of plane surfaces of paint coatings and plastics," German Institute for Standardisation, Berlin, Germany.

Esteves, B., and Pereira, H. (2008). "Wood modification by heat treatment: A review," BioResources 4(1), 370-404.

Feist, W. C., and Sell, J., (1987). "Weathering behavior of dimensionally stabilized wood treated by heating under pressure of nitrogen gas," Wood Fiber Sci 19, 183-195.

Ferrari, S., Cuccui, I., and Allegretti, O. (2013). "Thermo-vacuum modification of some European softwood and hardwood species treated at different conditions," BioResources 8(1), 1100-1109.

Gunduz, G., Aydemir, D., and Korkut, S. (2010). "The effect of heat treatment on some mechanical properties and color changes of uludag fir wood," Drying Technology 28(2), 249-255. DOI: 10.1080/07373930903530162

Gurleyen, L., Ayata, U., Esteves, B., and Cakicier, N., (2017). "Effects of heat treatment on the adhesion strength, pendulum hardness, surface roughness, color and glossiness of scots pine laminated parquet with two different types of UV varnish application," Maderas-Ciencia y Tecnologia 19(2), 213-224. DOI: 10.4067/S0718221X2017005000019.

Hidayat, W., Qi, Y., Jang, J. H., Febrianto, F., Kim, N. H. (2017). "Effect of mechanical restraint on the properties of heat-treated Pinus koraiensis and Paulownia tomentosa woods," BioResources 12(4), 7539-7551.

Hill, C. A. S. (2006). Wood Modification Chemical, Thermal and Other Processes, John Wiley \& Sons, Ltd., Hoboken, NJ, USA. DOI: 10.1002/0470021748

ISO 2813 (2014). "Paints and lacquer products - Determination of gloss value at 20 degrees, 60 degrees and 85 degrees," International Organization for Standardization, Geneva, Switzerland.

ISO 7724-2 (1984). "Paints and varnishes - Colorimetry - Part 2: Colour measurement," International Organization for Standardization, Geneva, Switzerland.

Kamperidou, V., Barboutis, I., and Vasileiou, V. (2013). "Response of colour and hygroscopic properties of Scots pine wood to thermal treatment," Journal of Forestry Research 24(3) 571-575. DOI: 10.1007/s11676-013-0389-y

Korkut, D. S., Hiziroglu, S., and Aytin, A. (2013). "Effect of heat treatment on surface characteristics of wild cherry wood," $\backslash$ BioResources 8(2), 1582-1590.

Krystofiak T., Bekhta, P., and Muszynska, M. (2014). "Effect of temperature of thermomechanical treatment of pine wood (Pinus sylvestris L.) veneers upon gloss and wettability," Annals of Warsaw University of Life Sciences 88, 126-129. 
Kučerová, V., Lagaňa, R., Výbohová, E., Hýrošová, T. (2016). “The effect of chemical changes during heat treatment on the color and mechanical properties of fir wood," BioResources 11(4), 9079-9094.

Kutnar, A., Kričej, B., Pavlič, M., and Petrič, M. (2013). "Influence of treatment temperature on wettability of Norway spruce thermally modified in vacuum," Journal of Adhesion Science and Technology 27(9), 963-972. DOI: 10.1080/01694243.2012.727168

Lee, S. H., Ashaari, Z., Lum, W. C., Halip, J. A., Ang, A. F., Tan, L. P., Chin, K. L., and Tahir, P. M. (2018). "Thermal treatment of wood using vegetable oils: A review," Construction and Building Materials 181, 408-419. DOI: 10.1016/j.conbuildmat.2018.06.058

Mitsui, K., Takada, H., Sugiyama, M., and Hasegawa, R. (2001). "Changes in the properties of light irradiated wood with heat treatment: Part 1. Effect of treatment conditions on the change in colour," Holzforschung 55(6), 601-605. DOI:

10.1515/HF.2001.098

Nemeth, R., Tolvaj, L., Bak, M., and Alpar, T. (2016). "Colour stability of oil heat treated black locust and poplar wood during short term UV radiation," Journal of Photochemistry and Photobiology A: Chemistry 329, 287-292. DOI: 10.1016/j.jphotochem.2016.07.017.

Rep, G., Pohleven, F., and Bucar, B. (2004). "Characteristics of thermally modified wood in vacuum," in: Proceedings of the IRG 35, Document No. IRG/WP 04-40287, 6-10, Ljubljana, Slovenia, pp. 1-9.

Sivrikaya, H., Can, A., de Troya, T., and Conde, M. (2015). "Comparative biological resistance of differently thermal modified wood species against decay fungi, Reticulitermes grassei and Hylotrupes bajulus," Maderas. Ciencia y Tecnología [Woods: Science and Technology] 17(3), 559-570. DOI: 10.4067/S0718221X2015005000050

Sivrikaya, H., Tesařová, D., Jeřábková, E., and Can, A. (2019). “Color change and emission of volatile organic compounds from Scots pine exposed to heat and vacuumheat treatment," Journal of Building Engineering 26, Article ID 100918. DOI: 10.1016/j.jobe.2019.100918

Srinivas, K., and Pandey, K. K. (2012). "Effect of heat treatment on color changes, dimensional stability, and mechanical properties of wood," Journal of Wood Chemistry and Technology 32(4) 304-316. DOI: 10.1080/02773813.2012.674170.

Surini, T., Charrier, F., Malvestio, J., Charrier, B., Moubarik, A., Castéra, P., and Grelier, S. (2012). "Physical properties and termite durability of maritime pine Pinus pinaster Ait., heat-treated under vacuum pressure," Wood Science and Technology 46(1-3) 487-501. DOI: 10.1007/s00226-011-0421-3.

Tjeerdsma, B. F., Boonstra, M., Pizzi, A., Tekely, P., and Militz, H. (1998). "Characterisation of thermally modified wood: Molecular reasons for wood performance improvement," European Journal of Wood and Wood Products Holz als Roh- und Werkst 56, 149-153. DOI: 10.1007/s001070050287

Tomak, E. D. (2011). "The effect of oil heat treatment and emulsion techniques on decreasing the leachability of boron in wood," Ph.D. Dissertation, Karadeniz Technical University, Trabzon, Turkey. 
Yang, Y., Zhang, T. Y., Lu, J. X., and Jiang, J. H. (2015). "Influence of thermo vacuum treatment on colours and chemical compositions of alder birch wood," BioResources 10(4), 7936-7945. DOI: 10.15376/biores.10.4.7936-7945

Yildiz, S., Gezer, E .D., and Yildiz, U. C. (2006). "Mechanical and chemical behavior of spruce wood modified by heat," Building and Environment 41(12), 1762-1766. DOI: 10.1016/j.buildenv.2005.07.017

Article submitted: December 19, 2019; Peer review completed: February 22, 2020; Revised version received and accepted: February 24, 2020; Published:

DOI: 10.15376/biores.15.2.2708-2720 